\title{
Potensi Antibakterial Bakteri Asam Laktat Proteolitik dari Bekasam Sebagai Biopreservatif Daging Sapi
}

\section{Antibacterial Potential of Proteolytic Lactic Acid Bacteria from Bekasam as Beef Biopreservatif}

\author{
Afriani $^{*}$, Arnim ${ }^{2}$, Y. Marlida ${ }^{2}$, dan Yuherman ${ }^{2}$ \\ ${ }^{1}$ Fakultas Peternakan, Universitas Jambi, 36361 \\ ${ }^{2}$ Fakultas Peternakan Universitas Andalas, Padang, 25163 \\ *E-mail: afrianiazis89@yahoo.com \\ (Diterima: 9 Agustus 2017; Disetujui: 23 September 2017)
}

\begin{abstract}
ABSTRAK
Tujuan penelitian ini adalah untuk mengetahui potensi antibacterial bakteri asam laktat proteolitik dari bekasam sebagai biopreservatif daging sapi. Penelitian ini menggunakan 3 isolat bakteri asam laktat proteolitik dengan cara merendam daging dalam substrat antibakterial dari isolat BAL tersebut kemudian disimpan pada suhu dingin. Pengamatan utama pada penelitian ini adalah : (1) kualitas fisik daging, (2) kualitas mikrobiologi. Penelitian ini menggunakan Rancangan Acak Lengkap (RAL) pola faktorial dengan 3 kali ulangan. Faktor A adalah jenis BAL proteolitik yaitu a1 = Lactobacillus pentosus BS15, a2 = Lactobacillus plantarum 1 BS22 dan a3 = Lactobacillus plantarum 1 BL12 dan faktor B adalah penyimpanan daging pada suhu dingin selama 2, 4 dan 6 hari. Kualitas fisik daging menunjukkan bahwa nilai $\mathrm{pH}$ daging yang diberi substrat antibakterial Lactobacillus pentosus BS15 lebih rendah dibandingkan dengan Lactobacillus plantarum 1 BS22 dan Lactobacillus plantarum 1 BL12 sedangkan lama penyimpanan tidak berbeda. Daya ikat air daging yang diberi substrat antibakterial ketiga jenis bakteri tidak berbeda sedangkan lama penyimpanan 2 hari dan 4 hari lebih tinggi dibandingkan dengan 6 hari. Susut masak daging yang diberi substrat antibakterial Lactobacillus pentosus BS15 lebih kecil dari pada Lactobacillus plantarum 1 BS22 dan Lactobacillus plantarum 1 BL12, penyimpanan 2 hari dan 4 hari lebih besar susut masaknya dibandingkan 6 hari. Kualitas mikrobiologi menunjukkan bahwa total mikroba daging yang diberi substrat antibakterial Lactobacillus pentosus BS15 lebih tinggi dibandingkan dengan Lactobacillus plantarum 1 BS22 dan Lactobacillus plantarum 1 BL12 dan penyimpanan 2 hari lebih tinggi dibandingkan dengan 4 hari dan 6 hari. Total $E$. coli dan total $S$. aureus menunjukkan tidak ada perbedaan sedangkan lama penyimpanan 2 hari lebih tinggi dibandingkan dengan 4 hari dan 6 hari. Kesimpulan dari hasil penelitian ini penggunaan substrat antibakterial dari BAL proteolitik dan penyimpanan pada suhu dingin dapat mempengaruhi kualitas fisik dan mikrobiologis daging yang lebih baik.
\end{abstract}

Kata kunci: BAL, biopreservatif, daging, substrat antibakterial

\section{ABSTRACT}

The purpose of this study was to investigate the antibacterial potential of proteolytic lactic acid bacteria from the former as biopreservative beef. This study used 3 isolates of proteolytic lactic acid bacteria by immersing the meat in the antibacterial substrate of the isolated BAL and then stored at cold temperatures. The main observations in this study were: (1) physical quality of meat, (2) quality of microbiology. This study used Completely Randomized Design (RAL) factorial pattern with 3 replications. Factor $A$ is a proteolytic BAL type that is a1 = Lactobacillus pentosus BS15, a2 = Lactobacillus plantarum 1 BS22 and a3 = Lactobacillus plantarum 1 BL12 and factor B is storage of meat at cold temperatures for 2, 4 and 6 days. The physical quality of the meat showed that the $p H$ value of the meat given the antibacterial substrate Lactobacillus pentosus BS15 was lower than that of Lactobacillus plantarum 1 BS22 and Lactobacillus plantarum 1 BL12 whereas storage time was no different. The binding capacity of the meat fed with the antibacterial substrate of the three types of bacteria was not different while the storage time of 2 days and 4 days was higher compared to 6 days. Meat cooked with antibacterial substrate 
Lactobacillus pentosus BS15 is smaller than in Lactobacillus plantarum 1 BS22 and Lactobacillus plantarum 1 BL12, 2 days' storage and 4 days greater shrinkage compared to 6 days. Microbiological quality showed that total of meat microbes given antibacterial substrate Lactobacillus pentosus BS15 were higher than Lactobacillus plantarum 1 BS22 and Lactobacillus plantarum 1 BL12 and storage 2 days higher compared with 4 days and 6 days. Total E. coli and total S. aureus showed no difference whereas 2 days'storage time was higher compared with 4 days and 6 days. The conclusion of the results of this study the use of antibacterial substrates from proteolytic BAL and storage at cold temperatures can affect the physical and microbiological qualities of better meat.

Keywords: antibacterial substrate, BAL, biopreservative, meat

\section{PENDAHULUAN}

Daging adalah salah satu produk pangan yang mudah rusak disebabkan daging kaya zat yang mengandung nitrogen, mineral, karbohidrat, dan kadar air yang tinggi serta $\mathrm{pH}$ yang dibutuhkan mikroorganisme perusak dan pembusuk untuk pertumbuhannya. Pertumbuhan mikroorganisme ini dapat mengakibatkan perubahan fisik maupun kimiawi yang tidak diinginkan, sehingga daging tersebut rusak dan tidak layak untuk dikonsumsi. Upaya mencegah terjadinya kerusakan dan pembusukkan oleh mikroorganisme dapat dilakukan dengan proses pengawetan.

Pengawetan dengan penggunaan senyawa antibakterial yang dihasilkan oleh food grade microorganisme merupakan suatu alternatif untuk pengendalian mikroba, yang dapat diisolasi dari bakteri asam laktat (BAL). Genus BAL penghasil antibacterial yang telah banyak diteliti dan dipublikasikan, di antaranya adalah Lactobacillus. Bakteri ini dapat menghambat pertumbuhan bakteri patogen maupun pembusuk serta perusak makanan sehingga dapat memperpanjang waktu penyimpanan. Produk metabolit tersebut antara lain diasetil, hidrogen peroksida, asam-asam organik dan bakteriosin (Galves, 2007). Bakteri asam laktat banyak ditemukan pada produk makanan fermentasi. Bekasam merupakan produk fermentasi secara spontan dengan bahan baku ikan air tawar. Bekasam merupakan salah satu sumber bakteri asam laktat (Desniar et al., 2011; Wikandari et al., 2012).

Penelitian ini bertujuan untuk mempelajari pengaruh substrat antibacterial
BAL dan lama penyimpanan terhadap kualitas fisik dan kualitas mikroba daging dengan BAL dan lama penyimpanan yang berbeda.

\section{METODE}

Bakteri asam laktat yang digunakan dalam penelitian ini adalah isolate bakteri Lactobacillus pentosus BS15, Lactobacillus plantarum 1 BS22 dan Lactobacillus plantarum 1 BL12 yang diisolasi dari bekasam (Afriani et al., 2015). Produksi substrat antibakterial dibuat dengan cara kultur ditumbuhkan dalam media MRS broth yang diperkaya dengan yeast ekstrak 3\% dengan $\mathrm{pH} 7$ dan diinkubasi pada incubator shaker selama $48 \mathrm{jam}$. Setelah itu disentrifuse dengan kecepatan $10.000 \mathrm{rpm}$ suhu $40^{\circ} \mathrm{C}$ selama 5 menit. Kemudian filtrat yang telah memisah dari pellet diambil yang merupakan substrat antimikroba (Sutandi, 2003)

Daging sapi daging bagian gandik (paha belakang) sebanyak 30 potong dengan ukuran masing-masing $10 \times 5 \times 5 \mathrm{~cm}$ (berat \pm 300 gram) dimasukkan ke dalam wadah yang bersih, kemudian direndam dalam substrat antibakterial selama 60 menit. Setelah itu dimasukkan ke dalam kantong plastik steril kemudian daging disimpan dalam refrigerator dengan selang waktu 2,4 dan 6 hari.

Peubah yang diamati adalah kualitas fisik daging : nilai $\mathrm{pH}$ (DSN, 1995), daya mengikat air (Hamm, 1972 dalam Soeparno, 2005), susut masak, dan keempukan (Swatland, 1984). Kualitas mikrobiologis: total mikroba, E. Coli, dan Staphylococcus aureus menurut petunjuk APHA, (1992).

Rancangan percobaan yang digunakan 
Tabel 1. Nilai $\mathrm{pH}$ daging berdasarkan jenis BAL dan lama penyimpanan pada suhu dingin.

\begin{tabular}{lcccc}
\hline \multirow{2}{*}{ Jenis Bakteri } & \multicolumn{3}{c}{ Lama Penyimpanan } & \multirow{2}{*}{ Rataan } \\
\cline { 2 - 4 } & 2 Hari & 4 Hari & 6 Hari & \\
\hline L. pentosus BS-15 & $5,22 \pm 0,03$ & $5,26 \pm 0,04$ & $5,19 \pm 0,07$ & $5,22 \pm 0,05^{\mathbf{b}}$ \\
L. plantarum1BS-22 & $5,52 \pm 0,15$ & $5,45 \pm 0,02$ & $5,53 \pm 0,04$ & $5,50 \pm 0,09^{\mathbf{a}}$ \\
L. plantarum 1BL-12 & $5,47 \pm 0,04$ & $5,50 \pm 0,04$ & $5,50 \pm 0,02$ & $5,49 \pm 0,03^{\mathbf{a}}$ \\
\hline Rataan & $5,41 \pm 0,16$ & $5,40 \pm 0,12$ & $5,41 \pm 0,17$ & \\
\hline
\end{tabular}

Keterangan: Superskrip yang berbeda pada kolom yang sama menunjukkan berbeda nyata $(\mathrm{P}<0,05)$.

adalah Rancangan Acak Lengkap (RAL) pola faktorial dengan 3 kali ulangan. Faktor pertama adalah 3 jenis BAL proteolitik yaitu $\mathrm{A} 1=$ Lactobacillus pentosus $\mathrm{BS} 15, \mathrm{~A} 2=$ Lactobacillus plantarum 1 BS22 dan A3 = Lactobacillus plantarum 1 BL12. Faktor kedua adalah lama penyimpanan pada suhu dingin $\left(4-7^{\circ} \mathrm{C}\right)$ yaitu 2,4 hari dan 6 hari.

Hasil analisis dicantumkan dalam tabel sidik ragam untuk mengetahui adanya pengaruh perlakuan. Untuk melihat perbedaan antar perlakuan digunakan Uji Tukey (Steel dan Torrie, 1995).

\section{HASIL DAN PEMBAHASAN}

\section{Kualitas fisik daging \\ Nilai pH Daging}

Nilai $\mathrm{pH}$ daging setelah direndam dalam substrat antibakterial isolate BAL proteolitik dan penyimpanan pada suhu dingin dapat dilihat pad Tabel 1. Dari hasil analisis diketahui pemberian substrat antibakterial mempengaruhi nilai $\mathrm{pH}$ daging $(\mathrm{P}<0,05)$ tetapi lama penyimpanan tidak mempengaruhi nilai $\mathrm{pH}$ daging $(\mathrm{P}>0,05)$ dan tidak terdapat interaksi antara keduanya.

Nilai $\mathrm{pH}$ daging sapi yang direndam dalam substrat antibakterial dari Lactobacillus pentosus BS 15 lebih rendah bila dibandingkan nilai $\mathrm{pH}$ dari substrat antibakterial Lactobacillus plantarum 1 BS22 dan Lactobacillus plantarum 1 BL12. Hal ini diduga antibakterial dari Lactobacillus pentosus BS15 lebih banyak mengandung asam organik. Asam organik merupakan salah satu metabolit bakteri asam laktat yang bersifat antibacterial.

Nilai $\mathrm{pH}$ daging tidak dipengaruhi oleh lamanya penyimpanan karena lama penyimpanan tidak mengubah kandungan substrat antibakterial pada daging sapi. Nilai $\mathrm{pH}$ yang rendah pada daging sapi dapat mempengaruhi stabilitas homeostatis dan terjadinya penguraian dan kerusakan membran sel. Asam laktat yang terbentuk akan masuk ke dalam sel bakteri sehingga terjadi pelepasan ion positif dan negatif di dalam membran yang tidak dapat keluar melalui membran sel (Aberle et al., 2000).

\section{Daya Mengikat Air Daging}

Daya mengikat air daging dengan menggunakan substrat antibakterial bakteri dan penyimpanan pada suhu dingin dapat dilihat pada Tabel 2. Pemberian substrat antibakterial tidak mempengaruhi daya mengikat air daging $(\mathrm{P}>0,05)$ tetapi lama penyimpanan mempengaruhi. Daya mengikat air daging $(\mathrm{P}<0,05)$ dan tidak terdapat interaksi antara keduanya.

Substrat antibakterial bakteri Lactobacillus pentosus BS 15, Lactobacillus plantarum 1 BS22 dan Lactobacillus plantarum 1 BL12 tidak mempengaruhi daya mengikat air pada daging. Daya mengikat air dipengaruhi oleh nilai $\mathrm{pH}$. Nilai $\mathrm{pH}$ daging yang direndam dalam substrat antibakterial Lactobacillus pentosus BS 15 lebih rendah bila dibandingkan nilai $\mathrm{pH}$ dari substrat antimikroba Lactobacillus plantarum 1 BS22 dan Lactobacillus plantarum 1 BL12. Namun demikian kisaran $\mathrm{pH}$ dari ke-tiga jenis bakteri ini sedikit berada di atas titik isoelektrik, Hal inilah yang menyebabkan daya mengikat air daging tidak berbeda. 
Tabel 2. Daya mengikat air daging berdasarkan jenis BAL dan lama penyimpanan pada suhu dingin $(\%)$.

\begin{tabular}{lcccc}
\hline \multirow{2}{*}{ Jenis Bakteri } & \multicolumn{3}{c}{ Lama Penyimpanan } & \multirow{2}{*}{ Rataan } \\
\cline { 2 - 4 } & 2 Hari & 4 Hari & 6 Hari & \\
\hline L. pentosus BS-15 & $39,67 \pm 3,54$ & $41,86 \pm 2,87$ & $28,56 \pm 2,44$ & $36,69 \pm 6,70$ \\
L. plantarum1BS-22 & $41,10 \pm 5,35$ & $43,22 \pm 4,77$ & $31,81 \pm 4,69$ & $38,71 \pm 6,77$ \\
L. plantarum1BL-12 & $42,84 \pm 0,47$ & $37,55 \pm 9,26$ & $30,10 \pm 1,14$ & $38,16 \pm 7,97$ \\
\hline Rataan & $41,21 \pm 3,50^{\mathrm{a}}$ & $40,88 \pm 5,98^{\mathrm{a}}$ & $30,49 \pm 3,22^{\mathrm{b}}$ & \\
\hline
\end{tabular}

Keterangan: Superskrip yang berbeda pada kolom yang sama menunjukkan berbeda nyata $(\mathrm{P}<0,05)$.

Tabel 3. Susut masak daging berdasarkan jenis BAL dan lama penyimpanan pada suhu dingin $(\%)$.

\begin{tabular}{lcccc}
\hline \multirow{2}{*}{ Jenis Bakteri } & \multicolumn{3}{c}{ Lama Penyimpanan } & \multirow{2}{*}{ Rataan } \\
\cline { 2 - 4 } & 2 Hari & 4 Hari & 6 Hari & \\
\hline L. pentosus BS-15 & $46,67 \pm 4,29$ & $49,83 \pm 0,77$ & $44,37 \pm 3,83$ & $46,96 \pm 3,75^{\mathbf{b}}$ \\
L. plantarum 1 BS-22 & $50,74 \pm 0,83$ & $51,18 \pm 1,18$ & $47,08 \pm 5,12$ & $49,67 \pm 3,30^{\mathbf{a}}$ \\
L. plantarum 1 BL-12 & $51,25 \pm 0,84$ & $54,54 \pm 0,18$ & $48,04 \pm 1,19$ & $51,28 \pm 3,00^{\mathbf{a}}$ \\
\hline Rataan & $49,55 \pm 3,11^{\mathbf{a}}$ & $51,85 \pm 2,21^{\mathbf{a}}$ & $46,50 \pm 3,71^{\mathbf{b}}$ & \\
\hline
\end{tabular}

Keterangan: Superskrip yang berbeda pada kolom dan baris yang sama menunjukkan berbeda nyata $(\mathrm{P}<0,05)$

Menurut Aberle et al. (2000) daya mengikat air daging menurun dari $\mathrm{pH}$ tinggi sekitar 7-10 sampai pada $\mathrm{pH}$ titik isoelektrik antara 5,0-5,1. Pada $\mathrm{pH}$ isoelektrik ini protein daging tidak bermuatan (jumlah muatan positif sama dengan jumlah muatan negatif) dan solubilitasnya rendah. Pada $\mathrm{pH}$ yang lebih tinggi dari $\mathrm{pH}$ isoelektrik protein daging, sejumlah muatan positif dibebaskan dan terdapat surplus muatan negatif yang mengakibatkan penolakan dari miofilamen dan memberi lebih banyak ruang untuk molekul air. Demikian pula pada $\mathrm{pH}$ lebih rendah dari titik isoelektrik protein terdapat ekses muatan positif memberi lebih banyak ruang untuk molekul-molekul air berikatan dengan protein daging.

Daya mengikat air daging pada penyimpanan 2 hari dan 4 hari tidak berbeda, mengalami penurunan setelah penyimpanan 6 hari. Hasil penelitian menunjukkan bahwa semakin lama penyimpanan, daya mengikat air semakin menurun. Hal ini disebabkan aktivitas mikroba merombak protein daging semakin tinggi sehingga kemampuan protein mengikat air masih menurun. Daya mengikat air berkisar antara 30,49-41,21 \%. Menurut Lawrie (1995) akumulasi asam laktat akan merusak protein miofibril yang diikuti oleh kehilangan kemampuan protein untuk mengikat air.

\section{Susut Masak Daging}

Rataan susut masak hasil penggunaan substrat antibakterial dan penyimpanan pada suhu dingin pada daging sapi dapat dilihat pada Tabel 3. Pemberian substrat antibakterial bakteri maupun lama penyimpanan mempengaruhi susut masak daging $(\mathrm{P}<0,05)$ namun tidak terdapat interaksi antara keduanya.

Susut masak daging yang direndam pada substrat antibakterial bakteri Lactobacillus pentosus BS 15 lebih rendah dari susut masak daging yang direndam dari bakteri Lactobacillus plantarum 1 BS22 dan Lactobacillus plantarum 1 BL12. Susut masak daging sapi dipengaruhi oleh daya mengikat air, semakin tinggi daya mengikat air daging, semakin rendah air bebas yang keluar dari daging. Menurut Soeparno (2005) bahwa 
Tabel 4. Nilai keempukan daging berdasarkan jenis BAL dan lama penyimpanan pada suhu dingin $\left(\mathrm{kg} / \mathrm{cm}^{2}\right)$.

\begin{tabular}{lcccc}
\hline \multirow{2}{*}{ Jenis Bakteri } & \multicolumn{3}{c}{ Lama Penyimpanan } & \multirow{2}{*}{ Rataan } \\
\cline { 2 - 4 } & 2 Hari & 4 Hari & 6 Hari & \\
\hline L. pentosus BS-15 & $4,13 \pm 0,51$ & $3,73 \pm 0,76$ & $3,60 \pm 0,62$ & $3,62 \pm 0,69^{\mathbf{b}}$ \\
L. plantarum1 BS-22 & $4,17 \pm 0,15$ & $4,27 \pm 1,50$ & $4,19 \pm 0,62$ & $4,21 \pm 1,12^{\mathbf{a}}$ \\
L. plantarum 1 BL-12 & $4,03 \pm 0,21$ & $4,07 \pm 0,31$ & $4,17 \pm 0,12$ & $4,09 \pm 0,31^{\mathbf{a}}$ \\
\hline Rataan & $4,11 \pm 0,57$ & $4,02 \pm 1,12$ & $4,05 \pm 0,59$ & \\
\hline
\end{tabular}

Keterangan: Superskrip yang berbeda pada kolom yang sama menunjukkan berbeda nyata $(\mathrm{P}<0,05)$

Tabel 5. Total mikroba daging berdasarkan jenis BAL dan lama penyimpanan pada suhu dingin (log cfu/gr).

\begin{tabular}{lcccc}
\hline \multirow{2}{*}{ Jenis Bakteri } & \multicolumn{3}{c}{ Lama Penyimpanan } & \multirow{2}{*}{ Rataan } \\
\cline { 2 - 4 } & 2 Hari & 4 Hari & 6 Hari & \\
\hline L. pentosus BS-15 & $5,18 \pm 0,40$ & $3,79 \pm 0,28$ & $3,88 \pm 0,05$ & $4,05 \pm 0,86^{\mathbf{a}}$ \\
L. plantarum 1 BS-22 & $5,23 \pm 0,13$ & $4,57 \pm 0,64$ & $4,59 \pm 0,07$ & $4,64 \pm 1,27^{\mathbf{b}}$ \\
L. plantarum 1 BL-12 & $5,04 \pm 0,21$ & $4,88 \pm 0,38$ & $4,93 \pm 0,22$ & $4,67 \pm 0,96^{\mathbf{b}}$ \\
\hline Rataan & $5,15 \pm 0,34^{\mathbf{a}}$ & $4,41 \pm 0,49^{\mathbf{b}}$ & $4,47 \pm 0,30^{\mathbf{b}}$ & \\
\hline
\end{tabular}

Keterangan: Superskrip yang berbeda pada kolom dan baris yang sama menunjukkan berbeda nyata $(\mathrm{P}<0,05)$

besarnya susut masak daging dipengaruhi oleh banyaknya air yang keluar dari dalam daging.

Susut masak daging pada penyimpanan 2 hari tidak berbeda dengan penyimpanan 4 hari dan mengalami penurunan pada penyimpanan 6 hari. Semakin lama penyimpanan, susut masak daging semakin meningkat. Hal ini disebabkan karena mikroba yang mengkontaminasi daging memanfaatkan protein yang terkandung dalam daging tersebut sehingga kemampuan protein untuk mengikat air berkurang mengakibatkan susut masak daging menjadi lebih besar. Nilai susut masak berkisar antara 46,50- 1,85\%. Nilai susut masak pada umumnya bervariasi antara 1,5-54,5\% dengan kisaran 15-40\%. Susut masak merupakan fungsi dari suhu dan lama pemasakan. Semakin tinggi temperatur pemasakan maka semakin besar kadar cairan yang hilang sampai sampai mencapai tingkat yang konstan (Soeparno, 2005).

\section{Keempukan Daging}

Hasil pengukuran keempukan daging sapi yang direndam dalam substrat antibakterial dari bakteri asam laktat proteolitik dan penyimpanan pada suhu dingin dapat dilihat pad Tabel 4. Pemberian substrat antibakterial mempengaruhi nilai keempukan daging $(\mathrm{P}<0,05)$ tetapi lama penyimpanan tidak mempengaruhi nilai keempukan daging $(\mathrm{P}>0,05)$ dan tidak terdapat interaksi antara keduanya.

Nilai keempukan daging sapi yang direndam dalam substrat antibakterial dari Lactobacillus pentosus BS 15 lebih empuk bila dibandingkan keempukan daging yang direndam substrat antimikroba dari Lactobacillus plantarum 1 BS22 dan Lactobacillus plantarum 1 BL12. Hal ini mungkin disebabkan oleh aktivitas enzim proteolitik yang dihasilkan oleh $L$. pentosus BS15 dalam mendegradasi serabut otot lebih tinggi sehingga meningkatkan nilai keempukan. Nilai keempukan berkisar antara3,62-4,21 ( $\left.\mathrm{kg} / \mathrm{cm}^{2}\right)$.

Hasil penelitian Arief et al. (2005) daging DFD yang difermentasi menggunakan L. plantarum dengan nilai keempukan 6,02 $\mathrm{kg} / \mathrm{cm}^{2}$ yang mempunyai keempukan lebih 
tinggi dibandingkan dengan daging DFD yang difermentasi alamiah dengan nilai daya iris (keempukan) $9,70 \mathrm{~kg} / \mathrm{cm}^{2}$. Menurut Pearson (1963), kisaran keempukan daging terbagi atas empuk dengan skala $0-3$, cukup/sedang dengan skala 3-6 dan alot dengan skala $>$ 6-11. Jika hasil pengukuran menunjukkan angka lebih dari 11 maka daging tersebut sulit dimakan manusia.

Nilai keempukan daging yang disimpan selama 2 hari, 4 hari dan 6 hari pada suhu dingin tidak mengalami perubahan. Hal ini diduga daging yang disimpan dalam suhu dingin (Refrigerator) aktivitas enzim rendah sehingga nilai keempukan daging selama penyimpanan tidak berbeda.

\section{Kualitas mikrobiologi Daging}

\section{Total Mikroba}

Hasil pengamatan aplikasi substrat antibakterial dan lama penyimpanan terhadap total mikroba pada daging disajikan pada Tabel 5. Pemberian substrat antibakterial maupun lama penyimpanan mempengaruhi total mikroba daging $(\mathrm{P}<0,05)$ namun tidak terdapat interaksi antara keduanya.

Total mikroba daging diberi substrat antibakterial Lactobacillus pentosus BS 15 lebih tinggi bila dibandingkan dengan Lactobacillus plantarum 1 BS22 dan Lactobacillus plantarum 1 BL12. Hal ini diduga disebabkan oleh aktivitas senyawa antibakterial yang dihasilkan oleh L. pentosus BS15 dalam lebih rendah bila dibandingkan dengan aktivitas antibakterial yang dihasilkan dari bakteri Lactobacillus plantarum 1 BS22 dan Lactobacillus plantarum 1 BL12 sehingga total mikroba yang dihasilkan masih tinggi. Menurut Galves (2007), antimikroba bersifat menghambat pertumbuhan bakteri atau kapang (bakteristatik atau fungistatik) atau membunuh bakteri atau kapang (bakterisidal atau fungisidal).

Total mikroba pada penyimpanan 2 hari nyata lebih tinggi bila dibandingkan total mikroba pada penyimpanan 4 hari dan 6 hari. Total mikroba menurun setelah penyimpanan 4 hari dan 6 hari. Hal tersebut disebabkan pada penyimpanan hari ke-2 mikroba masih dapat bertahan dengan lingkungannya dingin hingga penyimpanan hari ke-4 dan ke-6, mikroba tidak dapat bertahan pada lingkungannya sehingga tidak mampu untuk tumbuh dan berkembang biak. Besarnya populasi mikroba pada penyimpanan 2 hari karena bakteri yang tumbuh tergolong bakteri psikrofilik (bakteri yang tumbuh pada suhu $5-15^{\circ} \mathrm{C}$ ). Total mikroba berkisar antara 4,05$5,15(\log \mathrm{cfu} / \mathrm{gr})$. Syarat mutu daging sapi untuk jumlah mikroba maksimum adalah 5 x $10^{5} \mathrm{koloni} /$ gram (BSN, 1995), Besarnya populasi total mikroba selama penyimpanan karena bakteri yang tumbuh tergolong bakteri psikrofilik (bakteri yang tumbuh pada suhu $5-15^{\circ} \mathrm{C}$ ) (Surono, 2004) Hal ini diduga disebabkan penanganan yang kurang higienis dan sanitasi yang kurang baik sejak sapi dipotong sehingga menyebabkan kontaminasi oleh mikroorganisme pada daging. Soeparno (2005) menyebutkan bahwa bakteri psikrofilik yang ditemukan pada penyimpanan di suhu refrigerator adalah Pseudomonas, Achromobacter, Micrococcus, Lactobacillus, Streptococcus, Leuconostoc, Pediococcus, Flavobacterium dan Proteus.

\section{Total E. coli}

Total E. coli pada daging yang diaplikasi substrat antibakterial dan lama penyimpanan disajikan pada Tabel 6. Pemberian substrat antibakterial tidak mempengaruhi total $E$. coli $(\mathrm{P}>0,05)$ tetapi lama penyimpanan mempengaruhi total $E$. coli pada daging $(\mathrm{P}<0,05)$ dan tidak terdapat interaksi antara keduanya.

Total E. coli pada daging diberi substrat antibakterial Lactobacillus pentosus BS 15, Lactobacillus plantarum 1 BS22 dan Lactobacillus plantarum 1 BL12 tidak berbeda. Hal ini menunjukkan bahwa aktivitas substrat antibakterial dari ketiga bakteri ini dalam menghambat pertumbuhan E. coli pada daging relative sama.

Total E. coli pada penyimpanan 2 hari lebih tinggi $(\mathrm{P}<0,05)$ bila dibandingkan lama penyimpanan 4 hari dan 6 hari. Hal ini diduga 
Tabel 6. Total E. coli pada daging berdasarkan jenis BAL dan lama penyimpanan pada suhu dingin (log cfu/gr).

\begin{tabular}{lcccc}
\hline \multirow{2}{*}{ Jenis Bakteri } & \multicolumn{3}{c}{ Lama Penyimpanan } & \multirow{2}{*}{ Rataan } \\
\cline { 2 - 4 } & 2 Hari & 4 Hari & 6 Hari & \\
\hline L. pentosus BS-15 & $1,97 \pm 0,63$ & $1,09 \pm 0,18$ & $1,05 \pm 0,59$ & $1,37 \pm 0,47$ \\
L. plantarum 1 BS-22 & $1,92 \pm 0,19$ & $1,01 \pm 0,24$ & $1,13 \pm 0,28$ & $1,35 \pm 0,24$ \\
L. plantarum 1 BL-12 & $1,98 \pm 0,12$ & $1,03 \pm 1,05$ & $1,01 \pm 0,32$ & $1,34 \pm 0,18$ \\
\hline Rataan & $1,96 \pm 0,31^{\mathbf{a}}$ & $1,04 \pm 0,49^{\mathbf{b}}$ & $1,02 \pm 0,45^{\mathbf{b}}$ & \\
\hline
\end{tabular}

Keterangan: Superskrip yang berbeda pada baris yang sama menunjukkan berbeda nyata $(\mathrm{P}<0,05)$

Tabel 7. Total $S$. aureus daging berdasarkan jenis BAL dan lama penyimpanan pada suhu dingin ( $\log \mathrm{cfu} / \mathrm{gr})$.

\begin{tabular}{lcccc}
\hline \multirow{2}{*}{ Jenis Bakteri } & \multicolumn{3}{c}{ Lama Penyimpanan } & \multirow{2}{*}{ Rataan } \\
\cline { 2 - 4 } & 2 Hari & 4 Hari & 6 Hari & \\
\hline L. pentosus BS-15 & $1,94 \pm 0,47$ & $1,06 \pm 0,54$ & $1,10 \pm 0,20$ & $1,37 \pm 0,74$ \\
L. plantarum 1 BS-22 & $1,95 \pm 0,33$ & $1,09 \pm 0,05$ & $1,05 \pm 0,02$ & $1,36 \pm 0,20$ \\
L. plantarum 1 BL-12 & $1,89 \pm 0,33$ & $1,04 \pm 0,34$ & $1,08 \pm 0,48$ & $1,33 \pm 0,42$ \\
\hline Rataan & $1,92 \pm 0,46^{\mathbf{a}}$ & $1,06 \pm 0,40^{\mathbf{b}}$ & $1,07 \pm 0,28^{\mathbf{b}}$ & \\
\hline
\end{tabular}

Keterangan: Superskrip yang berbeda pada baris yang sama menunjukkan berbeda nyata $(\mathrm{P}<0,05)$

semakin lama daging disimpan dalam suhu dingin (refrigerator) aktivitas E. coli semakin menurun. Lama simpan dipengaruhi oleh suhu dan kecepatan udara di-refrigerator. Total E.coli berkisar antara 1,02 -1,96 (log cfu/gr). Total E,coli hasil penelitian ini cukup tinggi bila dibandingkan dengan aturan Standar Nasional Indonesia (SNI) 01-6366-2000 yang mensyaratkan batas maksimum cemaran E, coli pada daging adalah $5 \times 10^{1}$.

Beberapa strain bakteri E. coli dapat tumbuh pada suhu kurang dari $10^{\circ} \mathrm{C}$ dan termasuk bakteri anaerob fakultatif sehingga pertumbuhannya tidak dipengaruhi oleh suhu maupun kecepatan udara dalam refrigerator.

\section{Total S. Aureus}

Total S. aureus pada daging aplikasi dengan substrat antibakterial bakteri Lactobacillus pentosus BS 15, Lactobacillus plantarum 1 BS22 dan Lactobacillus plantarum 1 BL12 dan lama penyimpanan disajikan pada Tabel 7. Pemberian substrat antibakterial bakteri Lactobacillus pentosus BS 15, Lactobacillus plantarum 1 BS22 dan Lactobacillus plantarum 1 BL12 tidak mempengaruhi total $\mathrm{S}$. aureus $(\mathrm{P}>0,05)$ maupun lama penyimpanan mempengaruhi populasi total $S$. aureus $(\mathrm{P}<0,05)$ pada daging namun tidak terdapat interaksi antara keduanya.

Total S. aureus pada daging diberi substrat antibakterial bakteri Lactobacillus pentosus BS 15, Lactobacillus plantarum 1 BS22 dan Lactobacillus plantarum 1 BL12 tidak berbeda. Hal ini menunjukkan bahwa aktivitas substrat antibakterial dari ketiga bakteri ini dalam menghambat pertumbuhan $S$. aureus pada daging relative sama. Antibakterial yang lebih berperan dalam menghambat $S$. aureus adalah bakteriosin. Karena bakteriosin menghambat bakteri yang berkerabat dekat dengan penghasil bakteriosin tersebut. Penelitian yang dilakukan Fujita and Okamoto (1999), bahwa kelompok bakteri asam laktat dari Lactobacillus dapat memproduksi substansi antimicrobial dan bakteriosin yang bersifat bakterisidal terhadap mikroba patogen. Hasil penelitian Afriani et al. (2009) bahwa L. brevis dapat menghambat pertumbuhan $S$. aureus yang ditunjukkan dengan adanya zona hambatan sebesar 21,3 $\mathrm{mm}$. 
Total S. aureus pada penyimpanan 2 hari lebih tinggi $(\mathrm{P}<0,05)$ bila dibandingkan lama penyimpanan 4 hari dan 6 hari. Hal ini diduga semakin lama daging disimpan dalam suhu dingin (refrigerator) aktivitas $S$. aureus semakin menurun. Lama simpan dipengaruhi oleh suhu dan kecepatan udara di-refrigerator. Suhu yang digunakan (7$\left.4^{\circ} \mathrm{C}\right)$ dapat menghambat pertumbuhan $S$. aureus setelah hari ke-2 karena $S$. aureus merupakan bakteri anaerob fakultatif dan dapat hidup pada suhu antara $7-48^{\circ} \mathrm{C}$ dengan suhu optimum pertumbuhannya adalah $37^{\circ} \mathrm{C}$. Total S. aureus berkisar antara 1,07-1,39 (log cfu/gr). Populasi S. aureus pada daging segar ditetapkan dalam SNI 01-3818-1995 yaitu 1x101 untuk batas maksimumnya. Populasi $S$. aureus pada daging yang diuji telah melebihi ambang batas maksimum. S. aureus merupakan bakteri yang selalu ada di manamana seperti udara, debu, air, susu, makanan dan peralatan makan, lingkungan, tubuh manusia dan hewan seperti kulit, rambut/bulu, bahkan di dalam saluran pernafasan pada individu sehat bakteri ini dapat ditemukan (Nugroho, 2008).

\section{KESIMPULAN}

Berdasarkan hasil penelitian dapat disimpulkan :

1. Substrat antibakterial dari Lactobacillus pentosus BS 15, Lactobacillus plantarum 1 BS22 dan Lactobacillus plantarum 1 BL12 dan lama penyimpanan berpengaruh terhadap kualitas fisik dan mikrobiologis daging dan tidak terjadi interaksi antara keduanya.

2. Penggunaan substrat antibakterial dari Lactobacillus pentosus BS 15 memiliki $\mathrm{pH}$ dan susut masak yang rendah dan keempukan yang lebih tinggi. Lama penyimpanan 4 hari mampu meningkatkan daya mengikat air dan susut masak.

3. Penggunaan substrat antibakterial dari Lactobacillus pentosus BS 15 mampu menekan total mikroba daging. Lama penyimpanan 4 dan 6 hari mampu menekan pertumbuhan total mikroba, $E$. coli dan $S$. aureus.

\section{DAFTAR PUSTAKA}

Aberle, E. D., J. C. Forrest, H. B. Hendrick, M. D. Judge and R. A. Merkel. 2000. Principles of Meat Science. W.H. Freeman and Co. SanFransisco.

Adam, M. R. dan M. O. Moss. 1995. Food Microbiology. The Royal Society of Chemistry.

Afriani, Raguati dan P. Rahayu. 2009. Potensi Bakteri Asam Laktat Dadih dari Kabupaten Kerinci sebagai Biopreservatif Pangan. Laporan Penelitian. Fakultas Peternakan Universitas Jambi.

APHA (American Public Health Association). 1992. Standar Methods for The Examination of Dairy Products. 16th Ed. Port City Press., Washington D. C.

Arief, I. I., T. Suryati dan R.R.A.Maheswari. 2005. Sifat Fisik Daging Sapi Dark Firm Dry (DFD) Hasil Fermentasi BakteriAsam Laktat Lactobacillus plantarum. Media Peternakan, hlm. 7682 Vol. 29 No. 2.

Badan Standardisasi Nasional. 1995. Daging sapi/kerbau. SNI No. 01-3947-1995. BadanStandarisasi Nasional, Jakarta.

Desniar., R. Iman, S. Antonius, dan R. M. Nissa. 2011. Senyawa antimikroba yang dihasilkan bakteri asam laktat asal bekasam. Jurnal Akuatika Vol.3(2): 135-145.

Dewan Standarisasi Nasional. 1995. Standar Nasional Indonesia 01-3947. Daging Sapi. Standarisasi Nasional Jakarta Indonesia, Jakarta.

Fujita and Okomoto. 1999. Cloning and Identification of the Clustere Lactococcin A and M. Gene Cluster from Lactococcus lactis subsp. Lactis biovar diacetylactis. DRCi. JARQ 33: 133-7. 
Galvez, A., H. Abriouel, R. L. Lopez and N. B. Omar. 2007. Bacteriocin-base strategies for food biopreservation. Int J Food Microbio. 120:51-70.

Lawrie, R. A. 1995. Ilmu Daging. Terjemahan A. Parakkasi. Universitas Indonesia.

Nugroho, W. S. 2008. Aspek kesehatan masyarakat veteriner Staphylococcus, bakteri jahat yang sering disepelekan. http://weesnugroho.staff.ugm.ac.id.

Press, Jakarta, S. H. Moon and S. J. Parulekar. 1993. Some observation on protease producing in continuous suspention cultures of Bacillus firmus. Biotech. Bioeng. 41:43-54.

Soeparno. 2005. Ilmu dan Teknologi Daging. Gadjah Mada University Press Yogyakarta.
Stell, R. G. dan J. H. Torrie. 1995. Prinsip dan Prosedur Statistika. Terjemahan: B. PT. Gramedia Pustaka Utama, Jakarta.

Sutandi, C. 2003. Analisis potensi enzim protease lokal. [skripsi]. Bogor: Fakultas Teknologi Pertanian, Institut Pertanian Bogor.

Surono, I. 2004. Probiotik, Susu Fermentasi dan Kesehatan. PT Tri Cipta Karya, Jakarta.

Swatland, H. J. 1984. Structure and Developmentof Meat Animals. Prentice Hall, Inc., New Jersey.

Wikandari, P. R, Suparmo, M. Yustinus dan S. R. Endang. 2012. Karakterisasi Bakteri Asam Laktat Proteolitik pada Bekasam. Jurnal Natur Indonesia 14(2): 120-125. 